\title{
The Performance Improvement and the Competitiveness of Private Universities (PTS) in North Sumatera through the Strategy of Building Institutional Competence
}

\author{
Muhammad Yamin Siregar ${ }^{1}$, Parulian Sihombing ${ }^{2}$ \\ Faculty of Economic and Business, Universitas Meand Area, Indonesia \\ yaminsiregar@staff.uma.ac.id
}

\begin{abstract}
According to data released by DIKTI 2015 concerning the classification and ranking of the best 200 of higher education in Indonesia is only 5 universities from North Sumatera that are included in the list, both public and private universities. The purpose in this study is to examine whether there in an effect of learning orientation, internal environment and reputation on institutional competence. As well as to test whether there is an effect of competence on the achievement of institutional performance. The unit of analysis in this research is private universities. Respondents of this research were divided into 2 stages: Stage 1 is focused on the leadership of PTS (rector, vice chancellor I, II, or III; director, deputy director I, II, or III; chairman or vice chairman I, II, or III), where one PTS will be represented by one respondent. This study will describe the perceptions of PTS leader regarding organisational learning, the influence of internal environment, reputation, competence strategies and PTS performance. The second stage of respondent was extended to student suppliers, companies using graduate students, students, lectures, administration staff to describe the perception of the institutional competitiveness. The population in this study were all private universities in North Sumatera amounting 267 universities. This study uses 16 indicator so that the minimum sample requirement is 80 . The data was collected using questionnaire, while data measured by Likert scale. Data were analysed use Structural Equation Modelling (SEM) through Analysis of Moment Structure (AMOS) version 16.0 program.
\end{abstract}

Keywords

organisational learning, business environment; competence; performance; competitiveness

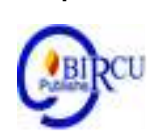

\section{Introduction}

The position of North Sumatra universities at the national level can be seen in the data released by DIKTI 2015 concerning Classification and Ranking of Higher Education 2015. The best 200 universities in Indonesia, only 5 universities from North Sumatera are included in the list, both state universities and private universities namely: ranked 29th Meand State University, ranked 38th North Sumatera University, ranked 94th Pancabudi Development University, ranked 158th Meand Area University, ranked 176th North Sumatera Muhammadiyah University. It is still far from satisfactory, considering that there are still many private universities in North Sumatera outside the top 200 positions, so it needs to be realized the quality and performance private universities in North Sumatera is still lagging. 
Changes that occur in the global business environment have also triggered an increase competitive intensity between providers of higher education services, so that each of them will strive to offer high quality of higher education services. Private universities must apply new perspective that contains elements of flexibility, speed, innovation, and integration. Flexibility, speed, innovation, and integration really require human resources who are full of creativity. Creativity can arise from human resources who have advantages in science. Thus PTS is expected not only to be able to produce the best graduated but also to be able to develop two things contained in the Tri Dharma of Higher Education, namely researching with high quality research result and develop technology for community services. For this reason PTS must always be able to adapt, develop, and make improvement through organisational learning (Henderson and Clockburn, 2004).

Barney and Hansen (2009) emphasize the importance of business environment, reputation in relation to sustainable competitive advantage.

The position of Indonesian universities in international level can also be seen in the list of the best universities in the world issued by QS World University Rankings 20162017. From the list that can be accessed in www.topuniversities.com, only 3 Indonesian PTN are included in the list of the world's 500 best universities namely: ranking 325 University of Indonesia, ranking 401-419 Bandung Institute of Technology, ranking 501550 Gajah Mada University. There are still many PTN's and private universities that have not been included in the list, so it can also be concluded that the quality of education in Indonesia is not evenly distributed.

Based on the description of the problem phenomenon above, the authors conducted research under the title "The Performance Improvement and the Competitiveness of Private Universities (PTS) in North Sumatera through The Strategy of Building Institutional Competence".

\section{Review of Literatures}

\subsection{The Current Condition of PTS in North Sumatera}

The position of North Sumatra universities at the national level can be seen in the data released by DIKTI 2015 concerning Classification and Ranking of Higher Education 2015. The best 200 universities in Indonesia, only 5 universities from North Sumatera are included in the list, both state universities and private universities, namely 2 PTN and 3 PTS. 3 PTS are Pancabudi Development University (ranked 94), Meand Area University (ranked 158), North Sumatera Muhammadiyah University (ranked 176). Even though the number of private universities in North Sumatra is 267 private universities, meaning that only $1.1 \%$ are in the 200 best category in Indonesia. This means that it can be concluded that the quality of private universities in North Sumatra is lagging behind other regions in Indonesia.

With the potential of Meand as the capital of North Sumatra, as the 3rd largest city in Indonesia, there should be more private universities from North Sumatra, especially Medan, which is included in the list of Indonesia's top 200. Therefore, a strategy is needed to build institutional competencies in order to improve the performance and competitiveness of private universities (PTS) in North Sumatra (website: kemenristek dikti, kopertis wilayah-1, 2017). 


\subsection{Research Variable}

There are 4 independent variables examined in this study, namely: organizational learning, internal environment, reputation, and competence. The organizational learning variable with indicator-1: commitment to learning means how leaders and employees provide the best service to customers (students, lecturers, companies, communities, other institutions, etc.) and commitment from all stakeholders to provide continuous improvement (continuous improvement) to their customers. Indicator-2: sharing the vision and goals of the institution. The vision and mission of the organization should be communicated and shared with all employees at each employee level, from top management to middle management to lower management. The vision and mission is not only a display on campus but is to be communicated and implemented. Leaders must always monitor how employees carry out the vision and mission of the institution, AB. Susanto (2008).

Indicator-3 is openness. All levels of the organization, from leaders to subordinates, must be open to improvement and willing to accept change. Feedback and coaching needs to be continuously provided to improve the performance of each division and every level of employees. The roles of university leadership starting from the Chancellor, Vice Chancellor, Dean, Deputy Dean, Chairperson, Deputy Chairperson, Study Program, lecturers are very important in their role to encourage this openness.

Internal environment variables with indicator-1: human resources (knowledge, skills, experiences, and judgment). The quality of human resources plays an important role in this matter. It is necessary to continuously monitor the knowledge, skills, experience, and assessment of employees in each case of the problem. It is necessary to map the position of each employee of the $4 \mathrm{HR}$ competencies so that the training needs they need are known according to their respective competencies and positions. Indicator-2: organizational structure: span of control or span of control. The control range that is too large or too little makes organizational control ineffective and inefficient. Need to adjust the organizational structure with the organizational strategy that has been prepared (Hitt, M. And R Duane Ireland, 2006).

Indicator-3: organizational culture. There are 3 important factors that need to be considered in building a competency culture in a company (corporate value), namely: leadership, capabilities, and systems. Leadership must be supported by employee systems and capabilities. The system means SOP (standard operating procedure) must exist, job descriptions must be neatly organized, job evaluation and weighting must be carried out well. Capability means competence in the form of knowledge, skills, attitude, behavior, and motivation. With the presence of a leader, system, employee capabilities, company culture will be formed AB. Susanto (2008).

\subsection{Operational Definition of Variable}

Table 1. Operational Definition of Variable

\begin{tabular}{|c|c|c|c|}
\hline Variable & $\begin{array}{c}\text { Operational Definition of } \\
\text { Variable }\end{array}$ & Indicator & Scale \\
\hline \multirow{4}{*}{$\begin{array}{l}\text { Organizational } \\
\text { Learning }\end{array}$} & \multirow{4}{*}{$\begin{array}{l}\text { Institutional expertise to create, } \\
\text { acquire, interpret, transfer and } \\
\text { share knowledge aimed at } \\
\text { modifying the behavior of its } \\
\text { members to develop new } \\
\text { knowledge and insights }\end{array}$} & Learning Commitment (X1) & \multirow{4}{*}{ Interval } \\
\hline & & $\begin{array}{l}\text { Share of Vition and } \\
\text { Institution Goals (X2) }\end{array}$ & \\
\hline & & Openness (X3) & \\
\hline & & & \\
\hline \multirow{3}{*}{$\begin{array}{c}\text { Internal } \\
\text { Environment }\end{array}$} & \multirow{3}{*}{$\begin{array}{l}\text { The environment within the } \\
\text { organization, which needs to be } \\
\text { analyzed to determine the } \\
\text { Strengths and Weaknesses (W) of } \\
\text { an organization }\end{array}$} & Human Resources (X4) & \multirow[b]{3}{*}{ Interval } \\
\hline & & Organitation Culture (X5) & \\
\hline & & $\begin{array}{l}\text { Internal Business Process } \\
\text { (X6) }\end{array}$ & \\
\hline
\end{tabular}




\begin{tabular}{|c|c|c|c|}
\hline \multirow{3}{*}{ Competence } & The company's ability to exploit & Management Quality (X7) & \multirow{3}{*}{ Interval } \\
\hline & \multirow{2}{*}{$\begin{array}{l}\text { divergent resources, using } \\
\text { different organizational } \\
\text { processes to achieve cool results }\end{array}$} & Curriculum Quality (X8) & \\
\hline & & Lecture Expertise Level (X9) & \\
\hline \multirow{4}{*}{ Performance } & \multirow{4}{*}{$\begin{array}{l}\text { A process or system for } \\
\text { assessing the implementation of } \\
\text { an organization's } r \text { work } \\
\text { capabilities based on certain } \\
\text { standards }\end{array}$} & Teaching Quality (X10) & \multirow{4}{*}{ Interval } \\
\hline & & Number of Research (X11) & \\
\hline & & $\begin{array}{l}\text { Readiness for Work } \\
\text { Graduates (X12) }\end{array}$ & \\
\hline & & $\begin{array}{l}\text { The Development of number } \\
\text { of students (X13) }\end{array}$ & \\
\hline \multirow{3}{*}{ Competitiveness } & \multirow{3}{*}{$\begin{array}{l}\text { An achievement that is more } \\
\text { than others in terms of quality } \\
\text { and has certain advantages }\end{array}$} & $\begin{array}{l}\text { Bargaining Power of Student } \\
\text { Supplier (X14) }\end{array}$ & \multirow{3}{*}{ Interval } \\
\hline & & $\begin{array}{l}\text { Bargaining Power of Student } \\
\text { User (X15) }\end{array}$ & \\
\hline & & Rivalry Competition (X16) & \\
\hline
\end{tabular}

\subsection{Previous Research}

1. Walter Obon (2014) in his research Developing the Quality of Competitive Strategies which Impacts on Company Performance (Case Study on White Stone Mill in Pati and Jepara Districts). The analysis technique used is Structural Equation Modeling (SEM) which is operated through the AMOS program. The results showed: The variable of business knowledge proved to have a significant positive effect on the quality of competitive strategies. The business experience variable is proven to have a significant positive effect on the quality of the competitive strategy. The business environment adaptability variable has a positive effect on the quality of the competitive strategy. Competitive strategy quality variable has a positive effect on company performance (sumber: eprints. undip.ac.id).

2. Nur Hayati (2013) in her research on High School Competitiveness Economics (Study of Leadership Capability Towards Market Orientation and Learning Orientation and Its Impact on the Performance and Competitiveness of Higher Schools of Economics in Kopugan Kopertis, West Java and Banten Areas Accredited Management Study Program B. This research uses quantitative methods. Data collection techniques with various methods: interviews, observation, questionnaires, and documentation The results showed: the leadership capability variable has a positive and insignificant effect on institutional performance, has a positive and significant effect on institutional competitiveness. Institutional competitiveness The variable of institutional performance has a positive and significant effect on the variable of institutional competitiveness (respository.upi.edu).

3. Dwi Suryanto Hidayat (2008) in his research on the UNDIP Postgraduate Thesis entitled Strategies to Build Organizational Competence in Order to Improve the Performance of Private Universities (PTS) in Central Java. The data analysis used was Structural Equation Modeling (SEM). The research model consists of 3 independent variables, namely: organizational learning, external environment, and reputation, which affect the dependent variable competence which in turn affects performance. This study consists of 24 indicators that are used to test the existence of a causal relationship between the variables being tested. The results showed that organizational learning abilities had a positive and significant effect on the competence of PTS. External environmental variables have a positive and significant effect on PTS competence. Reputation variable has a positive and significant effect on PTS competence. The competency variable has a positive and significant effect on PTS performance. External environmental variables have a positive and significant effect on PTS performance. Reputation variable has a positive and significant effect on PTS performance. 
4. Syardiansah, et al (2020) in their research on The Effect of Job Satisfaction and Organizational Culture on Employee Performance of the Royal Hotel in East Aceh District. The result showed that Job satisfaction has a positive and significant effect on employee performance at The Royal Hotel in East Aceh Regency. This is evidenced from the $t$ test in which the $t$ value of $0.029<0.05$ was obtained. Organizational culture has a positive and significant effect on employee performance at The Royal Hotel in East Aceh Regency. This is evidenced from the $t$ test in which the $t$-value of 0.035 $<0.05$ was obtained. Job satisfaction and organizational culture simultaneously have a significant effect on the performance of employees of The Royal Hotel in East Aceh Regency. This is evidenced from the F test where F sig $0.034<0.05$. From the results of the analysis of the coefficient of determination can be explained that job satisfaction and organizational culture affect the performance of employees of The Royal Hotel in East Aceh Regency by $58.6 \%$. While the remaining $41.4 \%$ is influenced by other variables not examined in this study.

\subsection{Originality of Research}

In previous research by Nur Hayati (2013), the independent variables studied were: leadership capability, market orientation. The dependent variable is the performance of the institution, which then affects the competitiveness of the institution. The research object of STIE Accreditation Management Study Program B in West Java and Banten. In Dwi Suryanto Hidayat's research (2008), the independent variables studied were organizational learning, external environment, and reputation. The dependent variable studied is competency which in turn affects performance. PTS research object in the Central Java Region. While the proposer proposes a study with 4 independent variables: organizational learning, internal environment, reputation, and competence. The dependent variable is the performance of the institution, which in turn affects the competitiveness of the institution. The object of research is private universities in North Sumatra Region. The complexity of the proposer problem is higher and more comprehensive than previous studies.

\subsection{Conceptual Framework}

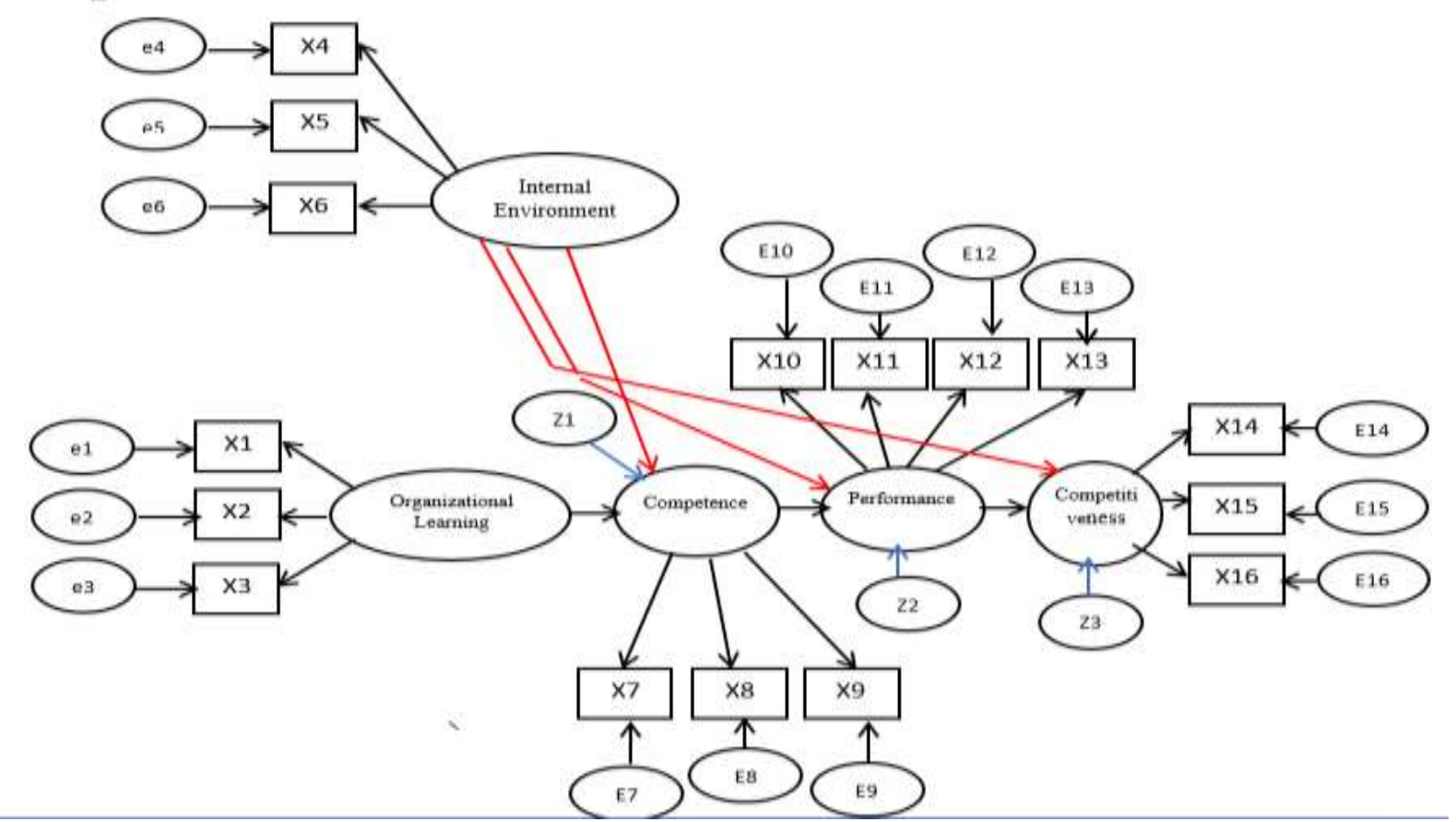

Figure 1. Conceptual Framework 


\subsection{Fishbone Diagram}

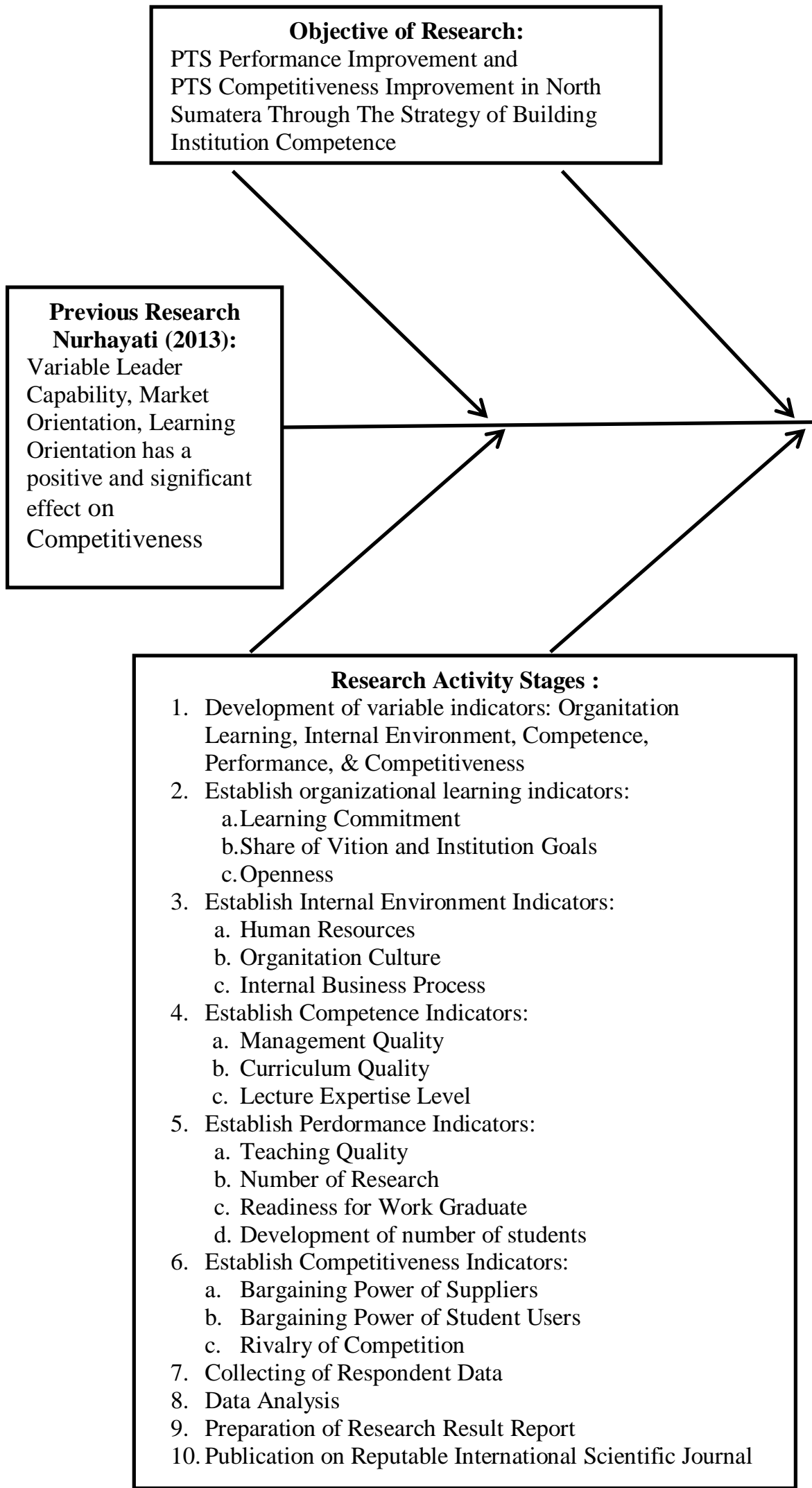

Figure 2. Fishbone diagram 


\section{Research Methods}

\subsection{Population and Sample}

The population in this study were all private universities in North Sumatra, amounting to 267 universities. Determination of the number of samples is done by considering the conditions that must be met when using SEM, namely the number of samples ranging from 100-200 and a minimum of five times the number of indicators. This study uses 16 indicators so that the minimum sample requirement is 80 . The unit of analysis in this study is PTS. Respondents This study was divided into 2 stages: Phase-1 focused on the leadership of PTS (rector or vice chancellor I, II, or III; director or deputy director I, II, or III; chairman or deputy chairman I, II, or III), where one PTS will be represented by one respondent. This study will use the perceptions of PTS leaders regarding organizational learning, the influence of the internal environment, reputation, competencies that will affect the performance of PTS and then affect the competitiveness of PTS. PTS leaders were chosen as respondents, because they were considered to be the most aware of the conditions in their PTS according to the variables in this study. Stage-2 the respondents were extended to student suppliers, namely high schools that supply many students so far, companies / institutions using or users of graduate students, students, lecturers, administrative staff to describe the competitiveness of the institution.

\subsection{Method of Data Collecting}

Primary data as well as secondary data in this study were collected by means of cross section, which is a one-time study using many respondents. The research data were collected in two ways; first to conduct interviews by coming directly to the research location; second, using a list of questions sent by mail.

\subsection{Data Analysis Technique}

The analysis technique is used to interpret and analyze the data. In accordance with the multidimensional and tiered model developed in this study, the data analysis used is Structural Equation Modeling (SEM). This study uses 2 kinds of analysis techniques: confirmatory factor analysis in SEM which is used to confirm the most dominant factor in a group of variables, and regression weight in SEM which is used to examine most of the relationships between variables.

\section{Results and Discussion}

\subsection{Research Results}

\section{a. Overview of Research Objects}

This research was conducted at 14 (fourteen) private universities in the city of Meand that provide undergraduate education (strata 1) for the Management Study Program. The fourteen universities are Meand Area University (UMA), North Sumatra Islamic University (UISU), HKBP Nommensen University (UHN), North Sumatra Muhammadiyah University (UMSU), Panca Budi Development University (UNPAB), Indonesian Methodist University (UMI), Darma Agung University (UDA), Prima Indonesia University (UNPRI), Santo Thomas Catholic University (UNIKA), Dharmawangsa University Meand (UDM), Muslimin Nusantara University (UMN), Harapan University, Sari Mutira University (USM) and College of Sciences Economics (STIE) Mikroskil. The Profile of the 14 Universities studied are summarized in the table 2 
Table 2. Profile of private universities studied

\begin{tabular}{|c|l|l|l|c|c|}
\hline No & \multicolumn{1}{|c|}{ Universities } & $\begin{array}{c}\text { Time of } \\
\text { Establishment }\end{array}$ & \multicolumn{1}{|c|}{ Managed by } & $\begin{array}{c}\text { Number } \\
\text { of } \\
\text { Faculties }\end{array}$ & $\begin{array}{c}\text { Number } \\
\text { of Study } \\
\text { Programs }\end{array}$ \\
\hline 1 & $\begin{array}{l}\text { Universitas Islam } \\
\text { Sumatera Utara }\end{array}$ & $07-01-1951$ & $\begin{array}{l}\text { Rektorat: Rektor, PR I, } \\
\text { PR II, PR III, and PR IV. }\end{array}$ & 9 & 32 \\
\hline 2 & $\begin{array}{l}\text { Universitas HKBP } \\
\text { Nommensen }\end{array}$ & $07-10-1954$ & $\begin{array}{l}\text { Rektorat: Rektor, WR I, } \\
\text { WR II, WR III \& WR IV. }\end{array}$ & 8 & 29 \\
\hline 3 & $\begin{array}{l}\text { Universitas } \\
\text { Pembangunan Panca } \\
\text { Budi }\end{array}$ & Tahun 1956 & $\begin{array}{l}\text { Rektorat: Rektor, WR I, } \\
\text { WR II, and WR III. }\end{array}$ & 8 & 17 \\
\hline 4 & $\begin{array}{l}\text { Universitas } \\
\text { Muhammadiyah } \\
\text { Sumatera Utara }\end{array}$ & $29-02-1957$ & $\begin{array}{l}\text { Rektorat: Rektor, WR I, } \\
\text { WR II, WR III, and } \\
\text { Sekretaris. }\end{array}$ & 9 & 35 \\
\hline 5 & $\begin{array}{l}\text { Universitas Darma } \\
\text { Agung }\end{array}$ & $11-12-1957$ & $\begin{array}{l}\text { Rektorat: Rektor, WR I, } \\
\text { WR II, and WR III. }\end{array}$ & 5 & 23 \\
\hline 6 & $\begin{array}{l}\text { Universitas Methodist } \\
\text { Indonesia }\end{array}$ & $01-08-1965$ & $\begin{array}{l}\text { Rektorat: Rektor, WR I, } \\
\text { WR II, and WR III }\end{array}$ & 10 & 23 \\
\hline 7 & $\begin{array}{l}\text { Universitas Meand } \\
\text { Area }\end{array}$ & Tahun 1983 & $\begin{array}{l}\text { Rektorat: Rektor, WR I, } \\
\text { WR II, WR III \& WR IV. }\end{array}$ & 7 & 20 \\
\hline 8 & $\begin{array}{l}\text { Universitas Katolik } \\
\text { Santo Thomas }\end{array}$ & Tahun 1984 & $\begin{array}{l}\text { Rektorat: Rektor, WR I, } \\
\text { WR II, WR III. }\end{array}$ & 8 & 21 \\
\hline 9 & $\begin{array}{l}\text { Universitas } \\
\text { Dharmawangsa }\end{array}$ & $22-05-1986$ & $\begin{array}{l}\text { Rektorat: Rektor, WR I, } \\
\text { W R II, and WR III.. }\end{array}$ & 5 & 10 \\
\hline 10 & $\begin{array}{l}\text { Universitas Muslim } \\
\text { Nusantara }\end{array}$ & Tahun 1996 & $\begin{array}{l}\text { Rektorat: Rektor, WR I, } \\
\text { WR II, WR III \& WR IV. }\end{array}$ & 6 & 14 \\
\hline 11 & $\begin{array}{l}\text { Universitas Prima } \\
\text { Indonesia }\end{array}$ & Tahun 2005 & $\begin{array}{l}\text { Rektorat: Rektor, WR I, } \\
\text { W R II, and WR III.. }\end{array}$ & 10 & 30 \\
\hline 12 & $\begin{array}{l}\text { Universitas Sari } \\
\text { Mutiara }\end{array}$ & $10-01-2013$ & $\begin{array}{l}\text { Rektorat: Rektor, WR I, } \\
\text { WR II, WR III \& WR IV. } \\
\text { Rektorat: Rektor, WR I, } \\
\text { WR II, WR III, WR IV. }\end{array}$ & 10 & 20 \\
\hline 13 & $\begin{array}{l}\text { Universitas Harapan } \\
\text { Medan }\end{array}$ & Tahun 2017, Kaprodi & 2 & 6 \\
\hline 14 & $\begin{array}{l}\text { STIE/STMIK } \\
\text { Mikroskil }\end{array}$ & 1997 & 5 & 10 \\
\hline
\end{tabular}

\section{b. Loading Factor for each Variable}

\section{Division of Organization}

Table 3. Regression Weights: (Group number 1 - Default model)

\begin{tabular}{|ll|rrrrr|}
\hline & & Estimate & S.E. & C.R. & P & Label \\
\hline X1 <--- & Division of Organization & 1,000 & & & & \\
X2 <--- & Division of Organization & 4,109 & 4,773 &, 861 &, 389 & par_1 \\
X3 <--- & Division of Organization & 2,435 & 1,531 & 1,590 &, 112 & par_2 \\
\hline
\end{tabular}

Table 4. Standardized Regression Weights: (Group number 1 - Default model)

\begin{tabular}{|c|c|}
\hline & Estimate \\
\hline $\begin{array}{lll}\text { X1 <-- } & \text { Division of Organization }\end{array}$ &, 183 \\
\hline X2<--- Division of Organization & ,766 \\
\hline X3 <--- Division of Organization & ,383 \\
\hline
\end{tabular}




\section{Organizational Environment}

Table 5. Regression Weights: (Group number 1 - Default model)

\begin{tabular}{|c|c|c|c|c|c|}
\hline & Estimate & S.E. & C.R. & $\mathrm{P}$ & Label \\
\hline X4<--- & 1,000 & & & & \\
\hline X5 <--- Intern & $-2,925$ & 2,165 & $-1,351$ & 177 & par_1 \\
\hline X6 <--- Internal Environment & $-5,656$ & 6,732 &,- 840 & 401 & par_2 \\
\hline
\end{tabular}

Table 6. Standardized Regression Weights: (Group number 1 - Default model)

\begin{tabular}{|ll|r|}
\hline & & Estimate \\
\hline X4 <--- & Internal Environment &, 157 \\
X5 <--- & Internal Environment &,- 438 \\
X6 <--- & Internal Environment &,- 734 \\
\hline
\end{tabular}

\section{Competence}

Table 7. Regression Weights: (Group number 1 - Default model)

\begin{tabular}{|ll|rcccc|}
\hline & & Estimate & S.E. & C.R. & P & Label \\
\hline X8 $<---$ & Competence &, 105 &, 623 &, 169 &, 866 & par_1 \\
X9 $<---$ & Competence &, 094 &, 563 &, 167 &, 867 & par_2 \\
X7 <--- & Competence & 1,000 & & & & \\
\hline
\end{tabular}

Table 8. Standardized Regression Weights: (Group number 1 - Default model)

\begin{tabular}{|rr|r|}
\hline & & Estimate \\
\hline X8 $<---$ & Competence &, 148 \\
X9 $<---$ & Competence &, 092 \\
X7 <--- & Competence & 1,451 \\
\hline
\end{tabular}

\section{Performance}

Table 9. Regression Weights: (Group number 1 - Default model)

\begin{tabular}{|c|c|c|c|c|c|}
\hline & Estimate & S.E. & C.R. & $\mathrm{P}$ & Label \\
\hline X10<--- Performance & 1,000 & & & & \\
\hline X11 <--- Performance &,- 097 & ,315 &,- 308 & ,758 & par_1 \\
\hline X12 <--- Performance & 3,110 & 1,330 & 2,339 & ,019 & par_2 \\
\hline X13 <--- Performance & 2,865 & 996 & 2,878 & ,004 & par_3 \\
\hline
\end{tabular}

Table 10. Standardized Regression Weights: (Group number 1 - Default model)

\begin{tabular}{|ll|r|}
\hline & & \multicolumn{1}{|c|}{ Estimate } \\
\hline X10 $<---$ & Performance &, 242 \\
X11 $<---$ & Performance &,- 028 \\
X12 $<---$ & Performance &, 961 \\
X13 <--- & Performance &, 801 \\
\hline
\end{tabular}

\section{Competitiveness}

Table 11. Regression Weights: (Group number 1 - Default model

\begin{tabular}{|ll|rrrrr|}
\hline & & Estimate & S.E. & C.R. & P & Label \\
\hline X14 $<---$ & Competitiveness & 1,000 & & & & \\
X15 $<---$ & Competitiveness & $-1,197$ & 1,768 &,- 677 &, 499 & par_1 \\
X16 <--- & Competitiveness & 22,560 & 129,458 & $, 174,862$ & par_2 \\
\hline
\end{tabular}


Table 12. Standardized Regression Weights: (Group number 1 - Default model)

\begin{tabular}{|c|c|}
\hline & Estimate \\
\hline X14 <--- Competi & ,059 \\
\hline X15 <--- Competitiveness &,- 074 \\
\hline X16 <--- Competitiveness & 1,206 \\
\hline
\end{tabular}

4.2 SEM Analysis Results

Table 13. Regression Weights: (Group number 1 - Default model

\begin{tabular}{|c|c|c|c|c|c|c|c|}
\hline & & & Estimate & S.E. & C.R. & $\mathrm{P}$ & Label \\
\hline & <--- & $\mathrm{Y} 1$ & 2,524 & 3,821 & ,660 & ,509 & par_3 \\
\hline Y3 & $<---$ & $\mathrm{Y} 2$ & $-1,779$ & 2,649 &,- 672 & ,502 & par_8 \\
\hline Y4 & $<--$ & Y3 &,- 001 & ,010 &,- 120 & ,904 & par_9 \\
\hline Y4 & $<--$ & Y1 & ,659 & ,256 & 2,573 & ,010 & par_14 \\
\hline Y5 & $<--$ & Y4 &,- 022 & ,116 &,- 194 & ,846 & par_13 \\
\hline Y5 & $<--$ & Y1 & ,630 & ,308 & 2,045 & ,041 & par_15 \\
\hline X3 & $<--$ & Y2 & 1,000 & & & & \\
\hline $\mathrm{X} 2$ & $<---$ & Y2 & ,725 & , 182 & 3,977 & $* * *$ & par_1 \\
\hline $\mathrm{X} 1$ & $<---$ & $\mathrm{Y} 2$ & ,302 & ,161 & 1,882 & ,060 & par_2 \\
\hline X9 & $<--$ & Y3 & 1,000 & & & & \\
\hline X8 & $<---$ & $\mathrm{Y} 3$ & ,000 & ,003 & ,118 & ,906 & par_4 \\
\hline X7 & $<--$ & Y3 & ,001 & ,009 &, 120 & ,904 & par_5 \\
\hline X12 & $<--$ & Y4 & 1,000 & & & & \\
\hline $\mathrm{X} 11$ & $<--$ & Y4 &,- 041 & ,087 &,- 476 & ,634 & par_6 \\
\hline $\mathrm{X} 10$ & $<---$ & Y4 & ,277 & , 136 & 2,042 &, 041 & par_7 \\
\hline X14 & $<--$ & Y5 & 1,000 & & & & \\
\hline $\mathrm{X} 15$ & $<--$ & Y5 & ,000 & ,000 & ,060 & ,952 & par_10 \\
\hline X16 & $<--$ & Y5 & ,000 & ,004 & ,071 & ,944 & par_11 \\
\hline $\mathrm{X} 13$ & $<--$ & Y4 & ,822 & , 150 & 5,497 & $* * *$ & par_12 \\
\hline X6 & $<--$ & Y1 & 1,000 & & & & \\
\hline X5 & $<--$ & Y1 & 1,694 & ,474 & 3,571 & $* * *$ & par_17 \\
\hline $\mathrm{X} 4$ & $<--$ & Y1 &,- 132 & ,212 &,- 619 &, 536 & par_18 \\
\hline
\end{tabular}

Table 14. Standardized Regression Weights: (Group number 1 - Default model)

\begin{tabular}{|c|c|c|c|}
\hline & & & Estimate \\
\hline & <--- & Y1 &, 08 \\
\hline Y3 & $<---$ & Y2 &,- 08 \\
\hline Y4 & $<---$ & Y3 &,- 01 \\
\hline 84 & $<---$ & Y1 & ,33 \\
\hline Y5 & $<---$ & Y4 &,- 00 \\
\hline 5 & $<---$ & Y1 & 01 \\
\hline X3 & $<---$ & Y2 & ,579 \\
\hline $\mathrm{X} 2$ & $<---$ & Y2 &, 49 \\
\hline $\mathrm{X} 1$ & $<---$ & Y2 & ,20 \\
\hline X9 & $<--$ & Y3 & 9,928 \\
\hline X8 & $<---$ & Y3 & ,004 \\
\hline X7 & $<---$ & Y3 &, 01 \\
\hline $\mathrm{X} 12$ & $<---$ & Y4 & 1,018 \\
\hline 11 & $<---$ & Y4 &,- 03 \\
\hline
\end{tabular}




\begin{tabular}{|c|c|}
\hline & Estimate \\
\hline $\mathrm{X} 10<---\quad \mathrm{Y} 4$ & 22 \\
\hline X14 <--- Y5 & 17,82 \\
\hline X15 <--- Y5 & 00 \\
\hline X16 <--- Y5 & 00 \\
\hline X13<--- Y4 & ,75 \\
\hline $\mathrm{X} 6 \quad<---\mathrm{Y} 1$ & ,39 \\
\hline X5 <--- Y1 & ,76 \\
\hline $\mathrm{X} 4<---\mathrm{Y} 1$ &,- 06 \\
\hline
\end{tabular}

Table 15. Total Effects (Group number 1 - Default model)

\begin{tabular}{|l|rrrrr|}
\hline & Y2 & Y1 & Y3 & Y4 & Y5 \\
\hline Y3 & $-1,779$ & 2,524 &, 000 &, 000 &, 000 \\
Y4 &, 002 &, 656 &,- 001 &, 000 &, 000 \\
Y5 &, 000 &, 615 &, 000 &,- 022 &, 000 \\
X4 &, 000 &,- 132 &, 000 &, 000 &, 000 \\
X5 &, 000 & 1,694 &, 000 &, 000 &, 000 \\
X6 &, 000 & 1,000 &, 000 &, 000 &, 000 \\
X13 &, 002 &, 539 &,- 001 &, 822 &, 000 \\
X16 &, 000 &, 000 &, 000 &, 000 &, 000 \\
X15 &, 000 &, 000 &, 000 &, 000 &, 000 \\
X14 &, 000 &, 615 &, 000 &,- 022 & 1,000 \\
X10 &, 001 &, 182 &, 000 &, 277 &, 000 \\
X11 &, 000 &,- 027 &, 000 &,- 041 &, 000 \\
X12 &, 002 &, 656 &,- 001 & 1,000 &, 000 \\
X7 &,- 002 &, 003 &, 001 &, 000 &, 000 \\
X8 &,- 001 &, 001 &, 000 &, 000 &, 000 \\
X9 & $-1,779$ & 2,524 & 1,000 &, 000 &, 000 \\
X1 &, 302 &, 000 &, 000 &, 000 &, 000 \\
X2 &, 725 &, 000 &, 000 &, 000 &, 000 \\
X3 & 1,000 &, 000 &, 000 &, 000 &, 000 \\
\hline
\end{tabular}

Table 16. Standardized Total Effects (Group number 1 - Default model)

\begin{tabular}{|l|rrrrr|}
\hline & Y2 & Y1 & Y3 & Y4 & Y5 \\
\hline Y3 &,- 089 &, 085 &, 000 &, 000 &, 000 \\
Y4 &, 002 &, 336 &,- 019 &, 000 &, 000 \\
Y5 &, 000 &, 014 &, 000 &,- 001 &, 000 \\
X4 &, 000 &,- 062 &, 000 &, 000 &, 000 \\
X5 &, 000 &, 767 &, 000 &, 000 &, 000 \\
X6 &, 000 &, 392 &, 000 &, 000 &, 000 \\
X13 &, 001 &, 254 &,- 015 &, 757 &, 000 \\
X16 &, 000 &, 000 &, 000 &, 000 &, 005 \\
X15 &, 000 &, 000 &, 000 &, 000 &, 001 \\
X14 &, 000 &, 247 &, 000 &,- 018 & 17,823 \\
X10 &, 000 &, 074 &,- 004 &, 221 &, 000 \\
X11 &, 000 &,- 013 &, 001 &,- 039 &, 000 \\
X12 &, 002 &, 342 &,- 020 & 1,018 &, 000 \\
X7 &,- 001 &, 001 &, 015 &, 000 &, 000 \\
\hline
\end{tabular}




\begin{tabular}{|l|rrrrr|}
\hline & Y2 & Y1 & Y3 & Y4 & Y5 \\
\hline X8 &, 000 &, 000 &, 004 &, 000 &, 000 \\
X9 &,- 883 &, 841 & 9,928 &, 000 &, 000 \\
X1 &, 204 &, 000 &, 000 &, 000 &, 000 \\
X2 &, 497 &, 000 &, 000 &, 000 &, 000 \\
X3 &, 579 &, 000 &, 000 &, 000 &, 000 \\
\hline
\end{tabular}

Table 17. Standardized Direct Effects (Group number 1 - Default model)

\begin{tabular}{|l|rrrrr|}
\hline & Y2 & Y1 & Y3 & Y4 & Y5 \\
\hline Y3 &,- 089 &, 085 &, 000 &, 000 &, 000 \\
Y4 &, 000 &, 337 &,- 019 &, 000 &, 000 \\
Y5 &, 000 &, 014 &, 000 &,- 001 &, 000 \\
X4 &, 000 &,- 062 &, 000 &, 000 &, 000 \\
X5 &, 000 &, 767 &, 000 &, 000 &, 000 \\
X6 &, 000 &, 392 &, 000 &, 000 &, 000 \\
X13 &, 000 &, 000 &, 000 &, 757 &, 000 \\
X16 &, 000 &, 000 &, 000 &, 000 &, 005 \\
X15 &, 000 &, 000 &, 000 &, 000 &, 001 \\
X14 &, 000 &, 000 &, 000 &, 000 & 17,823 \\
X10 &, 000 &, 000 &, 000 &, 221 &, 000 \\
X11 &, 000 &, 000 &, 000 &,- 039 &, 000 \\
X12 &, 000 &, 000 &, 000 & 1,018 &, 000 \\
X7 &, 000 &, 000 &, 015 &, 000 &, 000 \\
X8 &, 000 &, 000 &, 004 &, 000 &, 000 \\
X9 &, 000 &, 000 & 9,928 &, 000 &, 000 \\
X1 &, 204 &, 000 &, 000 &, 000 &, 000 \\
X2 &, 497 &, 000 &, 000 &, 000 &, 000 \\
X3 &, 579 &, 000 &, 000 &, 000 &, 000 \\
\hline
\end{tabular}

Table 18. Standardized Indirect Effects (Group number 1 - Default model)

\begin{tabular}{|l|rrrrr|}
\hline & Y2 & Y1 & Y3 & Y4 & Y5 \\
\hline Y3 &, 000 &, 000 &, 000 &, 000 &, 000 \\
Y4 &, 002 &,- 002 &, 000 &, 000 &, 000 \\
Y5 &, 000 &, 000 &, 000 &, 000 &, 000 \\
X4 &, 000 &, 000 &, 000 &, 000 &, 000 \\
X5 &, 000 &, 000 &, 000 &, 000 &, 000 \\
X6 &, 000 &, 000 &, 000 &, 000 &, 000 \\
X13 &, 001 &, 254 &,- 015 &, 000 &, 000 \\
X16 &, 000 &, 000 &, 000 &, 000 &, 000 \\
X15 &, 000 &, 000 &, 000 &, 000 &, 000 \\
X14 &, 000 &, 247 &, 000 &,- 018 &, 000 \\
X10 &, 000 &, 074 &,- 004 &, 000 &, 000 \\
X11 &, 000 &,- 013 &, 001 &, 000 &, 000 \\
X12 &, 002 &, 342 &,- 020 &, 000 &, 000 \\
X7 &,- 001 &, 001 &, 000 &, 000 &, 000 \\
X8 &, 000 &, 000 &, 000 &, 000 &, 000 \\
X9 &,- 883 &, 841 &, 000 &, 000 &, 000 \\
X1 &, 000 &, 000 &, 000 &, 000 &, 000 \\
\hline
\end{tabular}




\begin{tabular}{|r|rrrrr|}
\hline & $\mathrm{Y} 2$ & $\mathrm{Y} 1$ & $\mathrm{Y} 3$ & $\mathrm{Y} 4$ & $\mathrm{Y} 5$ \\
\hline $\mathrm{X} 2$ &, 000 &, 000 &, 000 &, 000 &, 000 \\
$\mathrm{X} 3$ &, 000 &, 000 &, 000 &, 000 &, 000 \\
\hline
\end{tabular}

\subsection{Model Fit Summary}

Table 19. CMIN

\begin{tabular}{|l|rrrrr|}
\hline Model & NPAR & CMIN & DF & P & CMIN/DF \\
\hline Default model & 55 & 343,983 & 97 &, 000 & 3,546 \\
Saturated model & 152 &, 000 & 0 & & \\
Independence model & 32 & 585,320 & 120 &, 000 & 4,878 \\
\hline
\end{tabular}

Table 20. Baseline Comparisons

\begin{tabular}{|l|rrrrr|}
\hline Model & $\begin{array}{r}\text { NFI } \\
\text { Delta1 }\end{array}$ & $\begin{array}{r}\text { RFI } \\
\text { rho1 }\end{array}$ & $\begin{array}{r}\text { IFI } \\
\text { Delta2 }\end{array}$ & $\begin{array}{r}\text { TLI } \\
\text { rho2 }\end{array}$ & CFI \\
\hline Default model &, 412 &, 273 &, 494 &, 343 &, 469 \\
Saturated model & 1,000 & & 1,000 & & 1,000 \\
Independence model &, 000 &, 000 &, 000 &, 000 &, 000 \\
\hline
\end{tabular}

Table 21. Parsimony-Adjusted Measures

\begin{tabular}{|l|rrr|}
\hline Model & PRATIO & PNFI & PCFI \\
\hline Default model &, 808 &, 333 &, 379 \\
Saturated model &, 000 &, 000 &, 000 \\
Independence model & 1,000 &, 000 &, 000 \\
\hline
\end{tabular}

Table 22. NCP

\begin{tabular}{|l|rrr|}
\hline Model & NCP & LO 90 & HI 90 \\
\hline Default model & 246,983 & 194,182 & 307,372 \\
Saturated model &, 000 &, 000 &, 000 \\
Independence model & 465,320 & 393,645 & 544,522 \\
\hline
\end{tabular}

Table 23. FMIN

\begin{tabular}{|l|rrrr|}
\hline Model & FMIN & F0 & LO 90 & HI 90 \\
\hline Default model & 2,309 & 1,658 & 1,303 & 2,063 \\
Saturated model &, 000 &, 000 &, 000 &, 000 \\
Independence model & 3,928 & 3,123 & 2,642 & 3,655 \\
\hline
\end{tabular}

Table 24. RMSEA

\begin{tabular}{|l|rrrr|}
\hline Model & RMSEA & LO 90 & HI 90 & PCLOSE \\
\hline Default model &, 131 &, 116 &, 146 &, 000 \\
Independence model &, 161 &, 148 &, 175 &, 000 \\
\hline
\end{tabular}

Table 25. AIC

\begin{tabular}{|l|rrrr|}
\hline Model & AIC & BCC & BIC & CAIC \\
\hline Default model & 453,983 & 468,149 & & \\
Saturated model & 304,000 & 343,152 & & \\
Independence model & 649,320 & 657,562 & & \\
\hline
\end{tabular}


Table 26. ECVI

\begin{tabular}{|l|rrrr|}
\hline Model & ECVI & LO 90 & HI 90 & MECVI \\
\hline Default model & 3,047 & 2,692 & 3,452 & 3,142 \\
Saturated model & 2,040 & 2,040 & 2,040 & 2,303 \\
Independence model & 4,358 & 3,877 & 4,889 & 4,413 \\
\hline
\end{tabular}

Table 27. HOELTER

\begin{tabular}{|l|rr|}
\hline \multirow{2}{*}{ Model } & HOELTER & HOELTER \\
& .05 & .01 \\
\hline Default model & 53 & 58 \\
Independence model & 38 & 41 \\
\hline
\end{tabular}

\section{Conclusion}

Organizational Learning significantly affects the performance and competitiveness of Higher Education, but this is not the case with the Internal Environment. The effect of organizational empowerment on increasing the competitiveness of higher education is not supported by competence. Competency variables have a positive and significant effect on PTS performance Organizational learning variables have a positive and significant effect on institutional performance but have no significant effect on institutional competitiveness. Institutional performance variables have a positive and significant effect on institutional competitiveness

It is suggested for further researchers it is recommended to examine more variable indicators for the competency, performance, and institutional competitiveness variables so that the research accuracy is expected to be better.

\section{References}

Aaker, DA., 2009. Strategic Market Management, Fourth Edition. John Wiley \& Sons, Inc. AB Susanto, 2008. Family Business. Edisi Kedua. Jakarta Consulting Group.

Ferdinand, A.T., 2002. Structural Equation Modeling Dalam Penelitian Manajemen: Aplikasi Model-model Rumit Dalam Penelitian untuk Tesis Magister dan Disertasi Doktor, Edisi 2, Semarang, BP Undip.

Hair, J.F., Anderson, R.E., Tatham, R.L., and Black, W.C., 2005. Multivariate Data Analysis, 7 th Edition, Prentice Hall, Upper Saddle River, USA.

HELTS (Higher Education Long Term Strategy), 2017. DIKTI Jakarta, diunduh dari internet, 26 Januari 2017.

Henderson, R., and I. Cockburn, 2004. Measuring Competence. Exploring Firm Effects in Pharmaceutical Research, Strategic Management Journal, Vol. 15, No.2, p.63.

Hidayat, D.S., 2013. Strategi Membangun Kompetensi Organisasi Dalam Rangka Meningkatkan Kinerja PTS di Jawa Tengah, Tesis, Program Pascasarjana UNDIP, Semarang.

Hitt, Michael, A.R Duane Ireland \& Robert E. Hoskisson., 2006. Manajemen Strategis. Edisi Kedua, Penerbit Erlangga, Jakarta.

Kaplan, Robert S, and Norton, David P., 2004. Strategy Maps: Converting Intangible Assets Into Tangible Outcomes, Boston, Massachussets, Harvard Business School Press.

Nur Hayati, 2013., Daya Saing (Competitiveness) Sekolah Tinggi Ilmu Ekonomi (Studi Tentang Kapabilitas Pimpinan Terhadap Orientasi Pasar, Orientasi Pembelajaran dan 
Dampaknya Terhadap Kinerja dan Daya Saing STIE di Lingkungan Kopertis Wilayah IV Jawa Barat dan Banten Prodi Manajemen Akreditasi B. Disertasi Doktor Universitas Pendidikan Indonesia (UPI). (sumber: perpustakaan.upi.edu/respository. upi.edu).

Obon, W, 2014. Mengembangkan Kualitas Strategi Bersaing yang Berdampak Pada Kinerja Perusahaan, Universitas Diponegoro Semarang. (sumber: eprints.undip.ac.id).

Syardiansah, et al. (2020). The Effect of Job Satisfaction and Organizational Culture on Employee Performance of the Royal Hotel in East Aceh District. Budapest International Research and Critics Institute-Journal (BIRCI-Journal). P. 849-857.

Wheelen, T.L., and J. David Hunger, 2002. Strategic Management and Business Policy Eight Edition, New Jersey: Prentice-Hall. 